\title{
THE IMPACT OF METAL AGE® TRAINING PROGRAMME ON THE WELL-BEING OF LATVIAN OFFICE WORKERS
}

\author{
Dagmāra Sprūdža\#, Lāsma Kozlova, Svetlana Lakiša, Inese Mārtiṇsone, \\ Ivars Vanadziṇš, Mārīte Ārija Baḳe, and Renārs Erts \\ Institute of Occupational Safety and Environmental Health, Rīga Stradiņš University, Dzirciema iela 16, Rīga, LV-1007, LATVIA \\ dagmara.sprudza@rsu.Iv; lasma.kozlova@rsu.Iv; svetlana.lakisa@rsu.Iv; inese.martinsone@rsu.lv; ivars.vanadzins@ @rsu.lv; \\ marite.bake@rsu.Iv; renars.erts@rsu.Iv \\ \# Corresponding author
}

Communicated by Māra Jure

\begin{abstract}
There are many factors that affect the well-being and health of employees and the productivity of organisations. The aim of this study was to determine the impact of the Metal Age training programme $\left(M A^{\circledR}\right)$ on the well-being of office workers, including investigation of work ability, the stress-causing factors and role of leadership. The study was carried out using questions from four international questionnaires about stress, leadership, and work ability. The intervention group had a training course between the surveys using the $M E^{\circledR}$ method. Several employee stress-causing factors were identified: bad relationship with their workmates was mentioned by $94 \%$ of workers; competitive and strenuous atmosphere - by more than $80 \%$; psychological violence or bullying at the workplace by more than $80 \%$, and more than $75 \%$ of employee's could not relax after work. Wellness and microclimate in the workplaces were on a relatively high level: the average rating of seven Kiva questions was 7.5. The respondent attitude after $M E^{\circledR}$ did not change significantly. Latvian office workers displayed moderate and good work ability (Work Ability Index, WAI 34.5-38.6). The best work ability was shown in the age group from 20 to 49 (WAl 34.8-39.4); work ability decreased with age. The best correlation was observed between Work Ability Index and "get into situations, that invoke negative feelings" $(r=0.26)$ and "carrying out ongoing tasks because of other intervening or more urgent matters" $(r=-0.24)$. After $M E^{\circledR}$ the reaction to some stress-causing factors was improved.
\end{abstract}

Key words: office workers, work ability, stress at work, social inclusion.

\section{INTRODUCTION}

The World Health Organization (WHO) defines a healthy workplace as one in which workers and managers collaborate to use a continual process to protect and promote the health, safety, and well-being of workers. These factors depend on the physical work environment and psychosocial work environment including work organisation and workplace culture (Anonymous, 2010).

While there are different definitions of what the concept entails within the European Union (EU), one widely used definition acknowledges that well-being is "a summative concept that characterises the quality of working lives, including occupational safety and health (OSH) aspects, and it may be a major determinant of productivity at the individual, enterprise and societal levels" (Schulte and Vainio, 2010). Otala and Ahonen (2005) described well-being at work as a subjective feeling and a state of mind and the activity level of the work environment. It is important to take into account all the different components of well-being at work; the mental, physical, social, and emotional well-being that affect each other. Some of the essential factors leading to well-being of workers are value-based working environment and management style involving open communication and dialogue; team working and co-operation; clarity and unity of purpose; management of work-related stress and work ability; flexibility, discretion and support for reasonable risk-taking; ensurance of balance between work and personal life; ability to negotiate workload and work pace without fear of reprisals or punishment as well as fair compensation in terms of salary and benefits (Otala and Ahonen, 2005).

Social inclusion is defined as the participatory, authentic, and accountable manner in which institutions uphold and reinforce the principles of access, equity and as a result providing social inclusion for all. Social inclusion is the management approach in which institutions understand and engage their communities as well as how they explore, view, and challenge barriers, values, and behaviours. Social inclusion is also defined by how institutions develop, implement, 
and evaluate policies and procedures, how they provide equitable access to services, and finally, how they demonstrate the level of inclusion through tangible outcomes. Social inclusion refers to all efforts and policies to promote equality of opportunity to people from all circumstances and from all socially-excluded categories. The circumstances and the categories of people mostly linked to social exclusion are therefore the circumstances and categories to be addressed by efforts to enhance inclusion (Fourie, 2007).

Improved well-being of workers at work and better social inclusion can be achieved through a combination of:

- improving the organisation of work and the working environment;

- promoting active participation;

- encouraging personal development (Baumann and Muijen, 2010).

Worldwide, millions of office workers work with computers. Recent literature reviews summarised the evidence of the relationship between the duration of work time spent using the computer and the incidence of hand-arm and neck-shoulder symptoms and disorders as well as reduction in work ability (Jmker et al., 2007; Malinska and Bugajska, 2010). Comprehensive and up-to-date knowledge on different dimensions of work ability is essential for the promotion of longer careers, employment growth and well-being of the population of working age. Work ability is defined as the ability of workers to perform their job, taking into account how demanding the work is, its physical and mental conditions (Ilmarinen and Tuomi, 2004). The concept of work ability was developed in the early 1980s in Finland and was later adopted in different European and Asian countries in more than 26 languages. The Work Ability Index (WAI) currently is by far the most used and well-accepted instrument on how to measure work ability (Tuomi et al., 1998).

Work ability is built on the balance between a person's resources and work demands Morschhäuser and Sochert, 2006). Improvement of work ability is one of the most effective ways to enhance the ability of person, to prevent disability and ensure the well-being of work and life.

Work-related stress is one of the basic problems around the world that affects well-being and health of employees as well as the productivity of organisations. Work-related stress has many causes including long working hours, heavy workload and job insecurity, the threat of job loss or redundancy, and conflicts with other workers or managers. Symptoms of work-related stress may include work ability decrease, fatigue, headaches, depression, and an increase in sick days or absenteeism (Tennant, 2001).

There are several studies about methods on how to improve well-being at work, reduce work-related stress and improve work ability. The "Druvan" model is one way of improving the working environment (Anonymous, 2008). The MA® training method is a structured method for developing the well-being at work and through that improving the profitability and the productivity in the organisations (Wolf and Karch, 2012). So far there have been no similar studies of MA® training as a tool for improvement of the working environment in Latvia.

The aim of this study was to determine the impact of MA® training programme on the well-being of office workers by investigation of their work ability, the stress-causing factors and role of leadership.

\section{MATERIALS AND METHODS}

Respondents. All together 636 respondents from 13 Latvian companies were invited to take part in the survey. The survey received the approval from the Ethics Commission of ARCADA University in Finland (2012) and was carried out with respect to the principles of the Declaration of Helsinki. Respondents were randomly divided into two groups: control and intervention group. Both groups were interviewed twice - in March / April 2012 (first stage) and in May / June 2013 (second stage). The intervention group had a training course between the surveys using the $\mathrm{ME}^{\circledR}$ method while the control group received no training.

According to the Statistical Classification of economic activities in the European Community (NACE Rev.2), two of the companies were working in the field of financing and insurance, two in the manufacturing of food production, three in public administration and the defence sector, two in communications (radio broadcasting and telecommunications), two in the transport industry and one in the education sector (all job tasks of respondents involved only or mostly office work with ICT and customers). Answers of 424 respondents were used for this study (response rate $66.7 \%$ ). $33.3 \%$ of questionnaires had a lot of missing data and were excluded from the study. Participants who responded to all the survey questions were selected for the study: 212 answers of participants from the intervention group and 212 from the control group. The participation in the study was voluntary. The results obtained in this study were analysed within each group comparing the results in two survey periods.

Questionnaire. Questionnaires for the survey was prepared using the questions from four questionnaires:

- General Nordic Questionnaire (QPSNordic) - 8 questions on „Leadership”,

- Occupational Stress Questionnaire (OSQ) - 33 questions,

- Kiva questionnaire - 7 questions,

- Work Ability Index Questionnaire (WAI) - 23 questions (Lindstom et al., 2000; Elo et al., 1992; Näsman, 2011; Rissa, 2007; Ilmarinen, 2007).

The Questionnaire was modified and adapted for office workers. It contained general information on demographic 
data (age, gender, marital statuss, education, work experience, type of work) and 48 questions about stressors in the following groups: modifying factors / resources at work, leadership, supervision, social relations and esteem, workplace atmosphere, work demands, responsibility and environment, stress and well-being, need for support, and interventions in job. Respondents were offered the following answers: "always", "quite often", "often", "time to time", "rather seldom", and "never". Answers from the Occupational Stress Questionnaire were grouped in two groups: "1 - not stressful" and "2 - stressful".

The Kiva questionnaire was used to examine personnel experience of work wellbeing and psychosocial microclimate at the working place. Each of the questions evaluated the employee's experience within a ten-point scale: from 1 ("not at all") to 10 ("yes, very much")".

The Work Ability Index Questionnaire consisted of the following seven items and with values ranging from 7-49 points:

1. Current work ability compared with the lifetime best comprised the work ability score that was often used as a separate indicator of work ability and was described above (0-10 points),

2. Work ability in relation to the demands of the job (2-10 points),

3. Number of current diseases diagnosed by a physician (1-7 points),

4. Estimated work impairment due to diseases (1-6 points),

5. Sick leave during the past year (1-5 points),

6. Own prognosis of work ability two years from now (1, 4 or 7 points),

7. Mental resources (1-4 points).

The Work Ability Index was then calculated by summing the points of the seven items (possible score ranging from 7 to 49 points). The index was divided into four groups (Table 1).

For easier data analsyis, subjects having 36 or less points were classified as having low work ability requiring improvements, subjects at or above 37 points were classified as having satisfactory work ability.

The results were analysed using the IBM SPSS-20 statistical package. $p$ values under 0.05 were considered signifi-

Table 1

WORK ABILITY INDEX

\begin{tabular}{lll}
\hline \multicolumn{1}{c|}{ Points } & Work ability & Objective of measures \\
\hline 7-27 points & poor & restore work ability \\
$28-36$ points & moderate & improve work ability \\
37-43 points & good & support work ability \\
$44-49$ points & excellent & maintain work ability
\end{tabular}

cant; however, a $p$ value under 0.1 was considered as close to statistical significance. Descriptive statistics were used to describe the characteristics of the study groups, including the analysis of age, gender, marital status, education, working experience, and work type. Spearman correlation analysis was performed for WAI and stress questions. The Wilcoxon or related t-test was used to compare related samples depending on data distribution. The Pearson's Chi square test for the comparison of independent categorical variables or McNemar test for related samples was used.

\section{RESULTS}

The characteristics of study groups (control and intervention) are shown in Table 2. Both study groups were similar in age, gender, education, and the type of work. In the intervention group $68.9 \%$ subjects who responded were women and in the control group - 69.3\%. The smallest number of people was in the age group 60. Most of the participants had higher education (the intervention group $-83.5 \%$ and the control group - 82.1\%). Individuals who participated in the study had a relatively small length of work experience - up to 9 years $(\sim 67.0 \%)$ and from 10 to 19 years

Table 2

CHARACTERISTICS OF THE STUDIED GROUPS

\begin{tabular}{|c|c|c|c|c|}
\hline \multirow{2}{*}{$\begin{array}{c}\text { Parameters } \\
\text { Total } \\
\end{array}$} & \multicolumn{2}{|c|}{ Control group } & \multicolumn{2}{|c|}{ Intervention group } \\
\hline & $\mathrm{n}=212$ & $100 \%$ & $\mathrm{n}=212$ & $100 \%$ \\
\hline \multicolumn{5}{|l|}{ Sex } \\
\hline women & 147 & 69.3 & 146 & 68.9 \\
\hline men & 65 & 30.7 & 66 & 31.1 \\
\hline \multicolumn{5}{|l|}{ Age group: } \\
\hline$<29$ & 72 & 34.0 & 79 & 37.3 \\
\hline $30-39$ & 68 & 33.1 & 62 & 29.3 \\
\hline $40-49$ & 25 & 11.8 & 27 & 12.7 \\
\hline $50-59$ & 34 & 16.0 & 33 & 15.6 \\
\hline$>60$ & 13 & 6.1 & 11 & 5.2 \\
\hline \multicolumn{5}{|l|}{ Marital status } \\
\hline married or cohabiting & 142 & 67.0 & 141 & 66.5 \\
\hline single & 43 & 20.3 & 39 & 18.4 \\
\hline $\begin{array}{l}\text { separated, divorced, } \\
\text { widowed }\end{array}$ & 27 & 12.7 & 32 & 15.1 \\
\hline \multicolumn{5}{|l|}{ Education } \\
\hline $\begin{array}{l}\text { secondary and special } \\
\text { education }\end{array}$ & 38 & 17.9 & 35 & 16.5 \\
\hline higher education & 174 & 82.1 & 177 & 83.5 \\
\hline \multicolumn{5}{|l|}{ Work experience } \\
\hline$<9$ & 142 & 67.0 & 141 & 66.5 \\
\hline $10-19$ & 55 & 25.9 & 54 & 25.5 \\
\hline $20-29$ & 8 & 3.8 & 11 & 5.2 \\
\hline $30-39$ & 2 & 0.9 & 3 & 1.4 \\
\hline 40 and $>50$ & 5 & 2.4 & 3 & 1.4 \\
\hline \multicolumn{5}{|l|}{ Type of work } \\
\hline mental work & 190 & 89.6 & 188 & 88.7 \\
\hline physical work & 1 & 0.5 & 1 & 0.5 \\
\hline $\begin{array}{l}\text { mental and physical } \\
\text { work }\end{array}$ & 21 & 9.9 & 23 & 10.9 \\
\hline
\end{tabular}


( $26.0 \%) .88 .7 \%$ of intervention group respondents and $89.6 \%$ control group respondents noted that they perform mental work and $\sim 10.0 \%$ of respondents in both groups noted that they perform both mental and physical (mixed) work, and only one person mentioned that he performs mostly physical work.

Stress factors. Regarding the QPS ${ }_{\text {Nordic }}$ questionnaire, answers to eight questions regarding the leadership's attitude towards an employee as a cause of stress showed that from $80.6 \%$ to $93.5 \%$ of control group cases superiors encouraged to participate in important decisions, helped to develop employees' skills, and tackled problems as soon as they come up, distributed the work evenly and treated workers fairly and impartially. However, the superiors did not encourage participating in important decisions for $25.8 \%$ of the employees and the relationship between superiors and employees was noted as potential cause of stress for $29.3 \%$ of employees. A similar situation was also observed in the second phase of survey. Also, in the intervention group the leadership's attitude to the employees did not cause stress both in the first and the second phase (before and after the $\mathrm{ME}^{\circledR}$ training). More than $85 \%$ (from $85.9 \%$ to $97.0 \%$ ) of employees believed that the leadership helped to build good working relationships. Before the training $23 \%$ of employee's answers showed that the leadership of the immediate superior did not encourage their participation in important decisions, while this increased to $25 \%$ after the training. Before the training, relationships with the leadership was the cause of stress for $22 \%$ of the employees while after the training $26.8 \%$ of employees noted it as the cause of stress.

Regarding the control group's OSQ answers, 33 stress characterizing questions in the first phase revealed that there are several factors (13) that may be the reason for stress at the workplace (the score higher than 10\%). $16.1 \%$ of the employees considered their relationship with colleagues as being rather negative, $11 \%$ were not getting positive evaluation by their family regarding their job, 29\% noted that the atmosphere at the workplace was competitive and stressful, 29\% noted that the workplace was not always encouraging and open to new ideas, $30 \%$ mentioned that sometimes there was psychological violence or bullying at workplace, $15 \%$ stated that there were difficult tasks to perform, $41.3 \%$ stated that there was a hurry to finish one's task, $41.9 \%$ that they had to suspend carrying out an ongoing task, and $16.1 \%$ noted that there was insufficient amount of discussion at a workplace in relation to aims and objectives of work tasks. $23.3 \%$ mentioned that they could accidentally ruin some valuable equipment or work result, more than a half of the employees had a mentally strenuous job $(60.2 \%), 41.9 \%$ experienced stress at a workplace and the majority of workers $(76.3 \%)$ were not able to relax after work.

In the second phase, the answers to questions regarding stress-causing factors improved in three cases: in relationships with colleagues (6.6\%) and family $(6.5 \%)$ and in the question about strenuous workplace atmosphere (22.8\%). However, some of the indicators declined: there was less possibility to influence situation at the work place $16.1 \%$, decreased employee's autonomy (25.8\%), there were situations at the workplace that caused indignation, fear, shame (12.9\%), there was insufficient amount of discussion regarding work tasks $(22.6 \%)$, and there was a possibility to ruin some valuable equipment or work result (32.2\%).

Comparison of the answers regarding the stress-causing factors between the first and second phase in the control group showed that there was a statistically significant difference $(p<0.05)$ in answers to 17 questions. Analysis of OSQ 33 stress questions in the intervention group in the first phase (Fig. 1) yielded similar results to those of the control group.

In the second phase, answers to seven questions regarding stress-causing factors improved: the possibility to influence the situation at the work place increased by $5.1 \%$, work autonomy increased by $78.2 \%$, more attention was paid to relationships with workmates $(11.9 \%)$, only $6 \%$ of the employees considered that they could have had better relationships with their colleagues and there was a need to hurry their job. $30.7 \%$ noted that the ongoing task must be suspended, $31.6 \%$ - that there is a possibility to accidentally ruin some valuable equipment or work result, and the number of the employees whose job was mentally strenuous decreased to $55.4 \%$. Also, the atmosphere at workplace became slightly more strenuous/competitive (30.7\%), the workplace was not so open and supportive of new ideas (74.3\%), psychological violence increased $(29.7 \%)$, and more employees experienced stress $(38 \%)$ and were not able to relax after work (62\%). The comparison of the answers to the questions regarding the stress-causing factors in the intervention group in the first and second phase (before and after the $\mathrm{ME}^{\circledR}$ training) showed that there were statistically significant differences $(p<0.05)$ in answers to 14 questions.

The workers' wellness and microclimate in offices was investigated using questionnaires based on the Kiva questionnaire. The KIVA questionnaire had 7 questions concerning the meaningfulness of job, the relationships with the employers and the fellow workers etc. Ratings were given within a ten points scale: from 1 ("not at all") to 10 ("yes, very much"). The results are shown in Table 3.

The results of wellness and microclimate at the workplace (Kiva questionnaire) were on a relatively high level: the average rating in the first phase of seven Kiva questions was 7.5. The employees enjoyed coming to work during the last week - 6.8 points; they assessed the work important to them - 8.1; they had control over their work process 7.6; the relationship with colleagues was good - 8.3; the direct superior acted good - 7.4; the staff was assured that they will continue their work for the same employer - 7.8, but the workers did not have influence on their own work process -6.3 .

Answers on seven Kiva questions that characterised the situation at work showed that the attitude of respondents had 


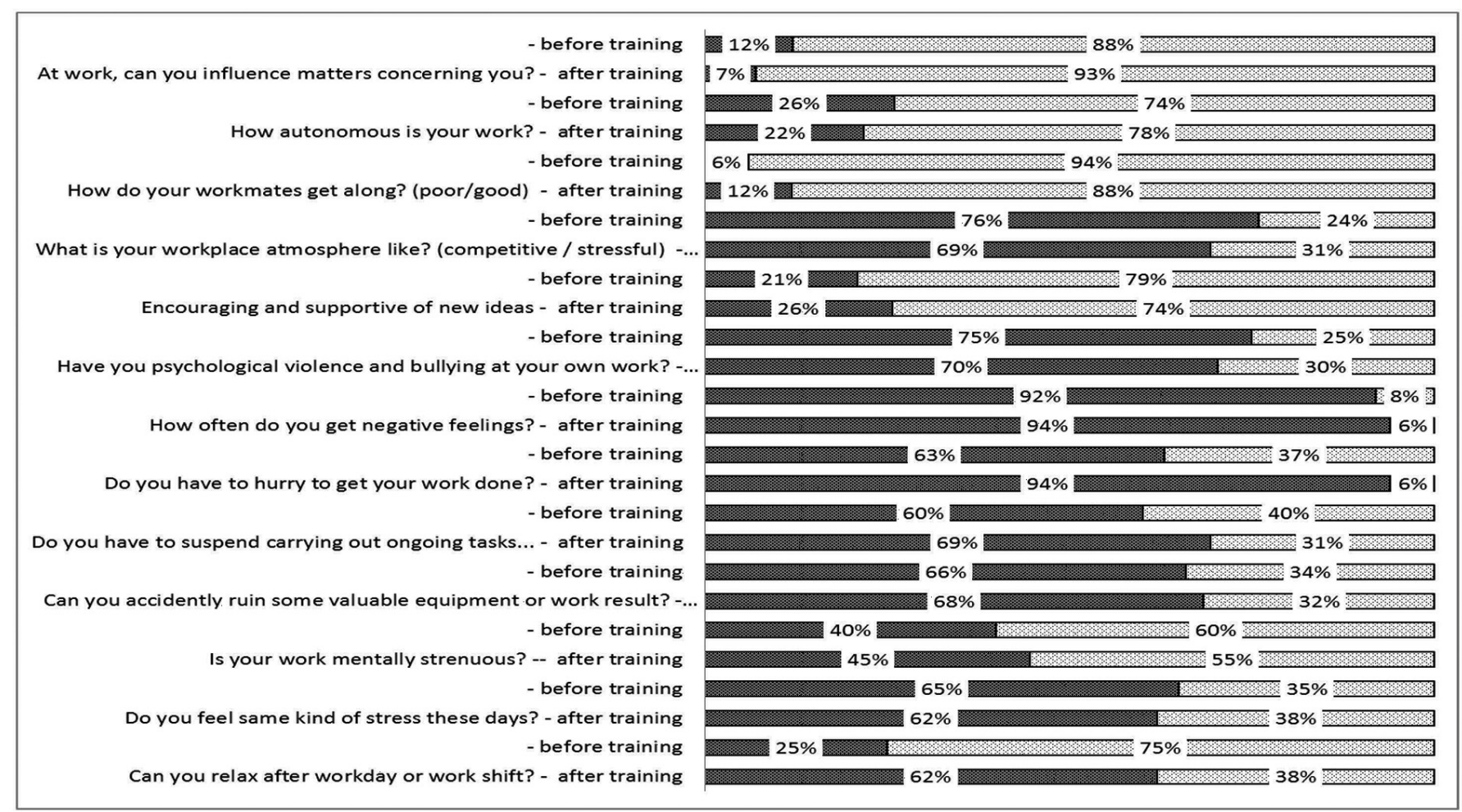

Fig. 1. Answers of respondents (\%) of stress issues according to the OSQ in the intervention group (answers were grouped in two groups: "not stressful"

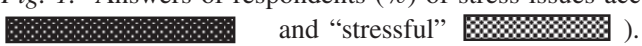

Table 3

ANSWERS OF KIVA QUESTIONNAIRES: 7 QUESTIONS AMONG LATVIAN OFFICE WORKERS (MEAN (SD))

\begin{tabular}{|c|c|c|c|c|c|}
\hline \multirow[t]{2}{*}{ KIVA questionnaires questions } & \multicolumn{2}{|c|}{ Intervention group } & \multicolumn{2}{|c|}{ Control group } & \multirow{2}{*}{$\begin{array}{c}\text { Difference in mean } \\
\text { change scores }(95 \% \mathrm{Cl}) *\end{array}$} \\
\hline & first period & second period & first period & second period & \\
\hline 1. Have you enjoyed coming to work in the last weeks? & $7.2(1.8)$ & $7.0(2.0)$ & $6.4(1.8)$ & $6.4(1.8)$ & $0.17(-0.5$ to 0.8$)$ \\
\hline 2. I regard my job meaningful & $8.2(1.4)$ & $8.1(1.5)$ & $8.1(1.4)$ & $8.2(1.4)$ & $0.28(-0.3$ to 0.8$)$ \\
\hline 3. I feel in control of my work & $7.6(1.7)$ & $7.5(1.6)$ & $7.5(1.5)$ & $6.7(2.1)$ & $-0.84(-1.5 \text { to }-0.2)^{* *}$ \\
\hline 4. I get on with my fellow-workers & $8.5(1.2)$ & $8.5(1.1)$ & $8.1(1.2)$ & $8.1(1.2)$ & $0.05(-0.4$ to 0.4$)$ \\
\hline 5. My immediate superior performs as superior & $7.9(1.7)$ & $7.8(2.0)$ & $6.8(2.3)$ & $6.5(2.3)$ & $-0.07(-0.7$ to 0.6$)$ \\
\hline $\begin{array}{l}\text { 6. How certain are you that you will keep your job } \\
\text { with this employer? }\end{array}$ & $8.0(2.0)$ & $7.6(2.1)$ & $7.6(1.8)$ & $7.0(2.0)$ & $-0.20(-0.9$ to 0.5$)$ \\
\hline $\begin{array}{l}\text { 7. How much can you influence factors concerning } \\
\text { your job? }\end{array}$ & $6.4(2.0)$ & $6.4(1.9)$ & $6.2(1.7)$ & $5.8(2.0)$ & $-0.49(-1.3$ to 0.3$)$ \\
\hline KIVA summary score & $53.7(8.7)$ & $52.8(9.1)$ & $50.7(8.1)$ & $48.8(9.4)$ & $-1.0(-4.0$ to 2.0$)$ \\
\hline
\end{tabular}

$* \mathrm{Cl}=$ confidence interval

** $p=0.013$

not changed significantly after training and the well-being at the second phase in both groups was similar. The only difference in work well-being was in the Kiva question "I feel in control of my work".

Work Ability Index (WAI). Both groups (control and intervention) were interviewed twice; for the intervention group, the second phase was after $\mathrm{ME}^{\circledR}$ training. Results of average WAI in the control and intervention group were compared in each group. The average work ability in first survey phase for both groups was moderate (respectively, $\mathrm{M}=35.3 ; \mathrm{SD}=3.2$ and $\mathrm{M}=34.5 ; \mathrm{SD}=4.8)$. After the second survey phase, the average WAI had changed statisti- cally significantly for the control group $(\mathrm{M}=44.8$; $\mathrm{SD}=$ $1.0)$ and for the intervention group $(\mathrm{M}=37.0 ; \mathrm{SD}=5.6)$ $(p<0.001)$.

The distribution of the WAI categories for all workers is shown in Table 4. WAI results in the control group during first period varied from 25 to 42 (excellent - $0 \%$ of respondents, good $-33.0 \%$, moderate $-64.6 \%$, poor $2.4 \%$ ); in intervention group it ranged from 19 to 48 (excellent $-1.9 \%$ of respondents, good $-26.4 \%$, moderate $63.2 \%$, poor $-8.5 \%$ ).

Distribution of respondents in WAI groups (excellent, good, moderate, poor) changed in the second survey period. WAI 
WORK ABILITY INDEX (WAI) SCORE DISTRIBUTION IN THE CONTROL AND INTERVENTION GROUPS

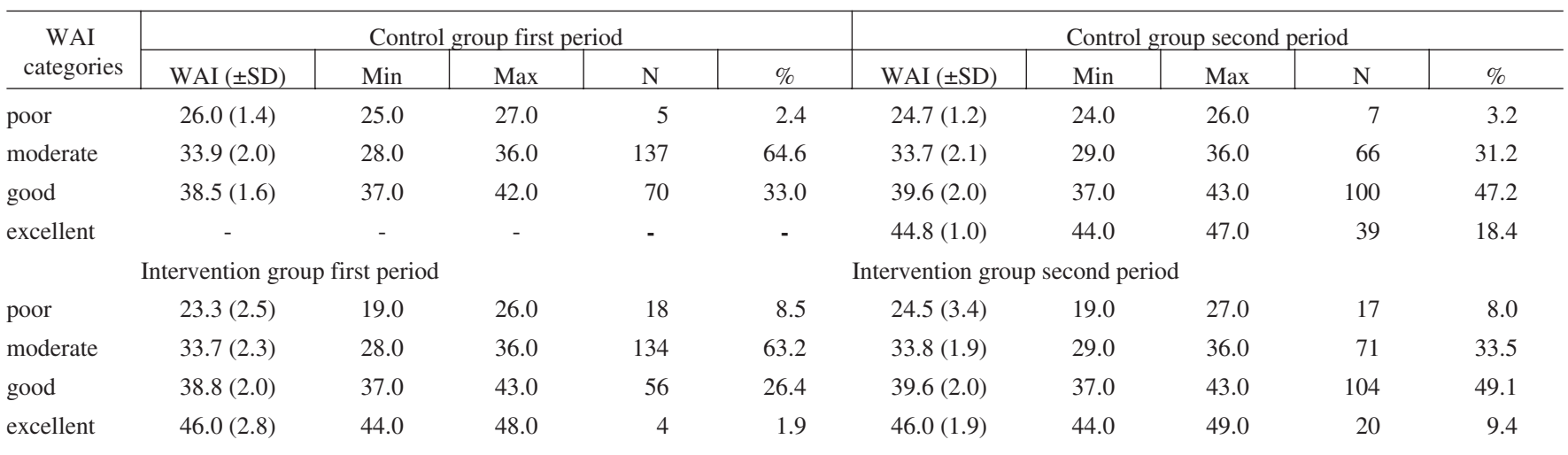

$\mathrm{SD}$, standard deviatiom

results in control group during the second period varied from 24 to 47 (excellent - 18.4\% of respondents, good $47.2 \%$, moderate $-31.2 \%$, poor $-3.3 \%)$; in the intervention group it ranged from 19 to 49 (excellent $-9.4 \%$ of respondents, good $-49.1 \%$, moderate $-33.5 \%$, poor $8.0 \%)$.

Table 5 shows the WAI depending on age, marital status, education and work experience and type of work in control and intervention groups (both phases). There were no statistically significant changes in the work ability for the mentioned indicators in the control group between the first and second stages. An exception was for respondents with secondary and special education - their WAI increased during the second phase.

Work ability of respondents of intervention group had a statistically significant increase depending on education, marital status and work experience (fs22 9 years) after $\mathrm{ME}^{\circledR}$ training.

Correlation between the WAI and stressful factors was tested using the Spearman's correlation coefficient. A statistically significant correlation was found between influence of superiors upon important decision making, assistance in the development of skills, work organisation, etc. $\left(\mathrm{QPS}_{\text {Nor- }}\right.$ dic questionnaire) and work ability in both control and intervention groups for both first and second periods.

Work ability and stress factors in the control group according to OSQ was significantly correlated only in two cases during first phase, but no correlation was found after the second period.

In the intervention group, significant correlation was found between work ability and stress causing factors, although it was weak.

No significant correlation was found in the control and intervention groups between work ability and relationships with immediate superior.

No correlation was found between work ability and OSQ stress questions about modifying factors/resources at work
(4 questions); social relations and esteem (5 questions); workplace atmosphere (2 questions); leadership and supervision (2 questions); perceived environment (7 questions); responsibility and environment (2 questions); work strain, stress and well-being (5 questions); need for support and interventions in your job (1 question).

\section{DISCUSSION}

In the present study answers of 424 employees about work abilities in 13 office companies were assessed; their age varied from 19 to 74 and one-third were females. $66.8 \%$ of the respondents were married or had a partner and $82.8 \%$ of the respondents had higher education. The majority of the employees (66.7\%) had relatively small work experience up to 9 years. Due to the nature of their jobs, $89 \%$ of respondents were engaged in mental work. The respondents were divided into two groups: the control group and the intervention group. Both groups were interviewed twice. The intervention group had a training course using the $\mathrm{MA}^{\circledR}$ training method between surveys; the control group lacked training.

According to the Kiva questionnaire the changes in wellness and microclimate in work places after $\mathrm{MA}^{\circledR}$ training were small. Based on the results of seven Kiva questions, well-being at work of Latvian office workers was on average on a good level -7.7 before training and 7.5 after $\mathrm{MA}^{\circledR}$ training. Therefore, it may have been difficult to improve well-being among these participants. Similar Estonian and Finnish studies also showed that the $\mathrm{MA}^{\circledR}$ training programme seldom improved KIVA results (Oha et al., 2012; Surraka, 2014). The average rating of seven Kiva questions was 7.8 of Finnish workers before and after training. It is more likely that the $\mathrm{MA}^{\circledR}$ training program has positive effect for well-being at work among workers with low work well-being assessment at baseline.

The concept of work ability relates to the capacity a worker has to perform his work tasks, given his work demands, health status, and physical and mental abilities and may be considered as a measure of functional aging (Ilmarinen, 
WORK ABILITY INDEX (WAI ( \pm SD) IF THE CONTROL AND INTERVENTION GROUPS ACCORDING TO AGE GROUPS, MARITAL STATUS, EDUCATION AND WORK EXPERIENCE

\begin{tabular}{|c|c|c|c|c|c|c|}
\hline \multirow[t]{2}{*}{ Parameters } & \multicolumn{3}{|c|}{ Control group } & \multicolumn{3}{|c|}{ Intervention group } \\
\hline & first period & second period & $p$ & first period & second period & $p$ \\
\hline \multicolumn{7}{|l|}{ Age group } \\
\hline$<29$ & $35.2(4.8)$ & $36.1(5.8)$ & n.s. & $33.8(4.8)$ & $38.8(5.0)$ & $<0.01$ \\
\hline $30-39$ & $36.0(4.4)$ & $37.0(6.1)$ & n.s. & $35.6(3.8)$ & $37.3(4.4)$ & n.s. \\
\hline $40-49$ & $34.8(3.6)$ & $39.4(4.2)$ & n.s. & $35.2(5.4)$ & $38.2(4.7)$ & n.s. \\
\hline $50-59$ & $33.9(3.0)$ & $38.7(4.4)$ & n.s. & $33.6(4.2)$ & $36.1(4.4)$ & n.s. \\
\hline$>60$ & $37.0(1.4)$ & $36.5(6.5)$ & n.s. & $34.0(2.2)$ & $37.7(6.5)$ & n.s. \\
\hline \multicolumn{7}{|l|}{ Marital status } \\
\hline unmarried & $35.6(4.0)$ & $37.1(6.1)$ & n.s. & $32.6(5.1)$ & $37.6(3.6)$ & $<0.001$ \\
\hline married & $35.0(4.2)$ & $37.2(5.3)$ & n.s. & $35.0(4.6)$ & $37.0(5.6)$ & $<0.01$ \\
\hline unmarried but co-habiting & $35.6(3.0)$ & $38.0(5.1)$ & n.s. & $35.8(3.4)$ & $40.1(5.0)$ & $<0.001$ \\
\hline separated & $34.2(4.1)$ & $33.2(9.0)$ & n.s. & - & - & \\
\hline divorced & $35.5(2.7)$ & $38.9(5.6)$ & n.s. & $32.3(4.3)$ & $36.6(2.6)$ & $<0.01$ \\
\hline widow/widower & $34.5(0.7)$ & $34.5(6.4)$ & n.s. & $34.0(1.0)$ & $40.3(3.2)$ & $<0.04$ \\
\hline \multicolumn{7}{|l|}{ Education } \\
\hline $\begin{array}{l}\text { secondary and special } \\
\text { education }\end{array}$ & $35.1(4.5)$ & $39.3(4.5)$ & $<0.03$ & $34.8(4.6)$ & $38.6(4.6)$ & $<0.05$ \\
\hline higher education & $35.3(3.3)$ & $36.8(4.8)$ & n.s. & $34.5(4.4)$ & $37.1(5.1)$ & $<0.001$ \\
\hline \multicolumn{7}{|l|}{ Work experience } \\
\hline$<9$ & $35.4(3.6)$ & $37.0(5.8)$ & n.s. & $33.6(4.7)$ & $38.2(5.2)$ & $<0.001$ \\
\hline $10-19$ & $34.9(4.6)$ & $38.0(4.8)$ & n.s. & $37.0(3.3)$ & $37.5(5.4)$ & n.s. \\
\hline $20-29$ & $35.6(2.3)$ & $39.5(4.8)$ & n.s. & $35.0(1.8)$ & $37.6(4.8)$ & n.s. \\
\hline $30-39$ & $35.5(3.5)$ & $31.0(3.8)$ & n.s. & $35.2(5.0)$ & $38.4(4.6)$ & n.s. \\
\hline 40 and $>50$ & - & - & - & $37.5(2.8)$ & $34.5(2.1)$ & n.s. \\
\hline \multicolumn{7}{|l|}{ Type of work } \\
\hline mental work & $35.2(3.6)$ & $37.3(5.3)$ & n.s. & $34.4(4.6)$ & $37.9(5.1)$ & n.s. \\
\hline physical work & - & - & - & - & - & - \\
\hline mixed work & $35.5(4.9)$ & $37.0(8.1)$ & n.s. & $36.0(2.8)$ & $38.3(4.1)$ & n.s. \\
\hline
\end{tabular}

SD, standard deviation; n.s., not statistically significant

2001). Work ability, which is regarded as a dynamic process of human resources in relation to work, is influenced by a number of factors that include sociodemographic characteristics, lifestyle, the aging process, and work demands (Martinez and Latorre, 2006). Work ability varies in different fractions of the population.

In this study Work Ability Index (WAI) was assessed before and after $\mathrm{MA}^{\circledR}$ training period. According to the WAI analysis, the majority of our study population showed moderate or good work ability - in the control group the average WAI was 35.3 and in the intervention group WAI was 34.5. The obtained WAI divided by class in the control group was excellent for none of respondents, good for $33.0 \%$, moderate for $64.6 \%$, poor for $2.4 \%$; in intervention group: excellent for $1.9 \%$ of respondents, good for $26.4 \%$, moderate for $63.2 \%$, poor for $8.5 \%$. For those whose WAI is moderate (score 28-36), improvement of work ability is recommended. Workers with a good WAI (score 37-43) should receive instructions on how to maintain their work ability. Those whose excellent work ability (44-49) should also be informed which work and life-style factors maintain work ability and which factors weaken it (Ilmarinen and Rantanen, 1999).

In the second phase, WAI was determined after the holiday period and average WAI increased in both groups — in the control group WAI was 38.6 (compared to WAI 35.3 in the first phase); in the intervention group WAI was 37.0 (compared to WAI 34.5 in the first phase). The WAI score difference in each group between the two survey periods significantly differred $(p<0.001)$.

Distribution of respondents in WAI groups (poor, moderate, good, excellent) changed during the second survey period: in the control group it varied from 24.0 to 47.0 (excellent $18.4 \%$ of respondents, good $-47.2 \%$, moderate $-31.2 \%$, poor $-3.2 \%$ ); in the intervention group it ranged from 19.0 to 49.0 (excellent $-9.4 \%$ of respondents, good $-49.1 \%$, moderate $-33.5 \%$, poor $-8.0 \%$ ).

These changes might be associated with a decrease in the number of persons with moderate work ability and increase 
in the number of employees with good and excellent work ability. After the training, WAI increased in the age group up to 29 years of age and was also linked with marital status and education in the intervention group. The control group did not display such changes. Studies carried out in other countries showed that office workers display excellent and good working abilities (Jmker et al., 2007). According to Finnish data, mostly people of working age evaluate their work ability as good (Tuomi et al., 2001).

The results of the present study indicated that WAI score was moderate and good (WAI 34.0-39.0) for employees with secondary and special education or higher education. Similarly, for a group of nurses (Golubic et al., 2009), respondents with higher educational levels had better work ability than their colleagues with lower educational level. Young and well-educated people perceive their work ability to be better than those who are older or have less education. Moreover, widows and single or divorced men report more problems concerning work ability than those who are married; white-collar workers report better work ability than blue-collar workers. Good work ability is evident only among those with higher education, physically light work and good health (Tuomi et al., 1997, 2001).

The changes in Work Ability Index for office workers had some positive improvements after $\mathrm{MA}^{\circledR}$ training, especially linked to the following factors: possibility to influence the situation at the workplace, more autonomous work, more attention to the relationships with workmates at the workplace, less hurry to finish one's task. The changes were also positively correlated with factors concerning psychologically strenuous job, more competitive work, not supportive workplace for new ideas and unability of employees to relax after a working day. Overall there was a weak correlation between stress-causing factors and work ability.

The consequences of stress on the individual level can reduce not only general quality of life but also well-being of the employee. For some people work-related stress can negatively affect their health. The most typical health problems linked to work-related stress are insomnia, constant tiredness, high blood pressure and nervous twitches (Greiner, 2008). The present study identified the main groups of occupational stressors in the control and intervention groups. In the control groups the following risks were identified: "perceived environment" (six stressors), "modifying factors/resources at work" (two stressors), "social relations and esteem" (two stressors), "workplace atmosphere" (two stressors), "responsibility and environment" (two stressors), and "stress and well-being" (two stressors). In the intervention group, slightly different results were obtained: "perceived environment" - three stressors, "modifying factors / resources at work" - two stressors, "workplace atmosphere" - two stressors, "responsibility and environment" - two stressors, "stress and well-being" - two stressors, and "social relations and esteem" — one stressor.

After MA ${ }^{\circledR}$ training, the possibility to influence the situations at a workplace increased by $5.1 \%$ in the intervention group, work autonomy increased by $4.2 \%$, and there was a $50 \%$ increase in more attention paid to relationship with workmates. There was an increase in the number of respondents who considered that the relationships at the workplace should be improved, there was no need to hurry to finish their job and suspend carrying out ongoing tasks, the chance to accidentally ruin some valuable equipment or the work result decreased, there was also a decrease in the number of employees who considered their work as mentally strenuous and stressful.

Poor communication with colleagues was one of the most common stressors at work. Good communication can protect from harmful effects of other stressors and can contribute to better safety at work. The concept of work ability presumes a modern concept of human ability for work conditions to worker's abilities and capabilities. A worker's psychophysical abilities change with time (Brešić, 2007).

Some studies show that stress at work can reduce safety of workers and work ability becomes lower with age and working time (Liu et al., 2001). The present study showed a statistically significant Spearman correlation in the intervention group between different stress-causing factors, e.g. "how often do you, at your work, get into situations that cause negative feeling"; "do you have to suspend carrying out ongoing tasks because of other intervention or more urgent matters" and work abilities prior to the training. However, this correlation was weak. Also, after the training, there was a weak correlation between the stress factors and work abilities: "at work, can you influence matters concerning you", "state of health compared with that of other people", and "satisfaction with present job".

According to results in Latvian companies and among Latvian employees, the $\mathrm{ME}^{\circledR}$ training programme as a method for improving of well-being at work seems to be rather effective, as analysis of several answers show improvements after the training and intervention programmes. This might also be explained by the fact that the initial level of work organisation and communication at office workplaces was rather low. Improvements with the $\mathrm{MA}^{\circledR}$ training method were mostly linked to better communication and exchange of information among employees and management.

\section{CONCLUSIONS}

1. The $M A^{\circledR}$ training programme as a method for improving well-being at work is effective. After $\mathrm{MA}^{\circledR}$ training the work ability improved in the age group up to 29 years and in the group with the working time up to nine years regardless of the family status and education

2. Office workers display moderate and good work ability. The best work ability was shown in the age group from 20 to 49 ; work ability decreased with the age.

3. Employee stress-causing factors include bad relationship with their workmates, competitive and strenuous atmosphere at the workplace, psychological violence or bully- 
ing at the workplace, the workplace not always being supportive and opened to new ideas, suspending carrying out ongoing task because of an urgent matter, insufficient amount of discussion at a workplace concerning the aims and tasks related to one's work, and possibility to accidentally ruin some valuable equipment or work result.

4. Approximately one half of the respondents considered their work well-being psychologically strenuous, employees experienced stress at their workplace and the majority of employees could not relax after work.

\section{ACKNOWLEDGEMENTS}

This research was supported by the Central Baltic Interreg IV A Programme 2007-2013 project ,, Work Ability and Social Inclusion” (WASI).

\section{REFERENCES}

Anonymous (2008). Druvan-projekti.

http://www.ebm-guidelines.com/dtk/shk/avaa?p_artikkeli=tt100505 (accessed 14.05.2015)

Anonymous (2010). Healthy Workplaces: a Model for Action: For employers, workers, policymakers and practitioners. WHO. 32 pp.

Brešić, J., Knežević, B., Milosevic, M., Tomljanović, T., Golubović, R., Mustajbegović, J. (2007). Stress and work ability in oil industry workers. Arch. Industr. Hygiene Toxicol., 58 (4), 399-405.

Baumann, A. Muijen, M. (2010). Mental Health and Well-being at the Workplace: Protection and Inclusion in Challenging Times. WHO. $50 \mathrm{pp}$.

Fourie, I. (2007). Public libraries addressing social inclusion: how we may think... In: Proceedings of the World Library and Information Congress: 73rd IFLA General Conference and Council, 19-23 August, Durban, South Africa. Available at:

http://www.ifla.org/iv/ifla73/index.htm (accessed 15.04.2015).

Elo, A. L., Leppanen, A., Lindstrom, K., Ropponen, T. (1992). Occupational Stress Questionnaire User's Instruction. Finnish Institute of Occupational Health, Helsinki. 47 pp.

Golubic, R., Milosevic, M., Knezevic, B., Mustajbegovic, J. (2009). Workrelated stress, education and work ability among hospital nurses. $J$. Adv. Nursing, 65 (10), 2056-2066

Gould, R., Ilmarinen, J., Järvisalo, J., Koskinen, S. (2008). Dimensions of Work Ability: Results of the Health Survey 2000. Helsinki. 185 pp.

Greiner, A. (2008). An economic model of work-related stress. J. Econ. Behav. Organiz., 66, 335-346.

IJmker, S. I., Huysmans, M. A., Blatter, B. M., van der Beek, A. J., van Mechelen, W., Bonger, P. M. (2007). Should office workers spend fewer hours at their computer? A systematic review of the literature. Occup. Environ. Med., 64, 211-222.

Ilmarinen, J. (2001). Aging and work. Occup. Environ. Med., 58, 546-552.

Ilmarinen, J. (2007). The Work Ability Index (WAI). Occupational Medicine, 58, 160 .

Ilmarinen, J., Rantanen, J. (1999). Promotion of work ability during ageing. Amer. J. Industr. Med., 21-23.
Ilmarinen, J., Tuomi, K. (2004). Past, Present and Future of Work Ability. People and Work. Research Reports 65. Finnish Institute of Occupational Health, Helsinki. 25 pp.

Kirsten, W., Karch, R. C. (2012). Global Perspectives in Workplace Health Promotion. Jones \& Bartlett Learning. 494 pp. (at pp. 176-178).

Lindstom, K., Elo, A. L., Skogstad, A., Dallner, M., Gamberale, F., Hottinen, V., Knardahl, S., Orhede, E. (2000). User's Guide for the QPS Nordic General Questionnaire for Psychological and Social Factors at Work. TemaNord. $74 \mathrm{pp}$.

Liu, J., Wang, Z., Wang, M., Lan, Y. (2001). Factors of occupational stress on the working ability of petroleum workers. Wei Sheng Yan Jiu, 30 (5), 263-265 (in Chinese).

Malinska, M., Bugajska, J. (2010). The influence of occupational and non-occupational factors on the prevalence of musculoskeletal complaints in users of portable computers. J. Occup. Safety Ergon. (JOSE), 16 (3), $337-343$.

Martinez, M. C., Latorre, M. (2006). Health and work ability among office workers, Rev. Saśde Pśblica (Sćo Paulo), 40 (5), 1-7.

Morschhäuser, M., Sochert, R. (2006). Healthy Work in an Ageing Europe, Strategies and Instruments for Prolonging Working Life. Federal Association of Company Health Insurance Funds, Essen. 76 pp.

Näsman, O. MA® and Kiva-questionnaire. Assist in navigation towards well-being at work. Mediona OyAb. The Archipelago Academy for Well-being at Work. Available at:

http://www.mediona.fi/pdf/KANSI\%20Metal\%20Age\%20ja\%20Kiva-ky sely\%20ENG.pdf. (accessed 29.04.2015).

Oha, K., Pille, V., Lauri, M., Tint, P., Tuulik-Leisi, V., Tuulik, V. and Meigas, K. (2012). The health risks connected with monotonous work by computers. Available at:

http://www.ttu.ee/public/t/Tehnomeedikum/Instituudid/Biomeditsiinitehnika_instituut/WASI/Artikklid201401/Tint_The_health_risks_Publ_ of_Riga_Stradins_Univ_Dec_2012.pdf (accessed 14.05.2015).

Otala, L., Ahonen, G. (2005). Well-being at Work [Työhyvinvointi tuloksentekijänä]. Helsingfors: WSOYpro (in Finnish).

Rissa, K., Kaustia, T. (2007). Well-being creates productivity: The Druvan-Model. Helsinki Centre for Occupational Safety, Helsinki.

Schulte, P., Vainio, H. (2010). Well-being at work: Overview and perspective. Scand. J. Work Environ. Health, 36, 5, 422-429.

Surakka, J. (2014). The Work Ability and Social Inclusion. Arcada Working Papers, 7, 86.

Tennant, C. (2001). Work-related stress and depressive disorders. $J$. Psychosom. Res., 51, 697-704.

Tuomi, K., Huuhtanen, P., Nykyri, E., Ilmarinen, J. (2001). Promotion of work ability, the quality of work and retirement. Occup. Med. (Oxford), 51 (5), 318-324.

Tuomi, K., Ilmarinen, J., Seitsamo, J., Huuhtanen, P., Martikainen, R., Nygård, C.-H., Klockars, M. (1997). Summary of the Finnish research project (1981-1992) to promote the health and work ability of aging workers. Scand. J. Work Environ. Health, 23, 66-71.

Tuomi, K., Ilmarinen, J., Martikainen, R., Aalto, L., Klockars, M. (1997). Aging, work, life-style and work ability among Finnish municipal workers in 1981-1992. Scand. J. Work Environ. Health, 23, 58-65.

Tuomi, K., Ilmarinen, J., Jahkola, A., Katajarinne, L., Tulkki, A. (1998). Work Ability Index. 2nd edition. Finnish Institute of Occupational Health, Helsinki. 19 pp. 


\section{METAL AGE ${ }^{\circledR}$ APMĀCĪBAS PROGRAMMAS IETEKME UZ BIROJU DARBINIEKU LABSAJŪTU}

Ir daudz faktoru, kas ietekmē darbinieku labklājību, veselību un organizācijas produktivitāti. Šì pētījuma mērḳis bija noteikt Metal Age® $\left(M A{ }^{\circledR}\right)$ apmācības programmas ietekmi uz biroja darbinieku labsajūtu, novērtējot viņu darba spējas, stresa izraisošos faktorus un vadītāja lomu. Pētījums tika veikts, izmantojot jautājumus no četrām starptautiskām anketām par stresu, vadītāja lomu un darba spējam. Intervences grupas dalībniekiem tika veikta apmācība, izmantojot $M A{ }^{\circledR}$ apmācības metodi, kontroles grupai apmācības netika veiktas. Konstatēti faktori, kas rada stresu darbā vietā: sliktas attiecības ar kolēǵiem (94\%), konkurētspējīga un spraiga atmosfēra (80\%), psiholoğiska vardarbība vai iebiedēšana $(80 \%)$, vairāk nekā $75 \%$ darbinieku nevar atpūsties pēc darba. Labsajūta un mikroklimats darba vietā ir salīdzinoši labā līmenī: vidējais vērtējums pēc Kiva aptaujas ir 7,5. Respondentu attieksme pēc MA® apmācības nav būtiski mainījusies. Latvijas biroja darbinieki uzrāda mērenas un labas darba spējas (Darba spēju indekss, DSI = 34,5-38,6). Labākas darba spējas konstatētas vecuma grupā 20-49 gadi (DSI = 34,8-39,4); darba spējas samazinājās līdz ar lielāku vecumu. Tika atrasta korelācija starp darba spēju indeksu un "nokḷūt situācijā, kas rada negatīvas sajūtas" vai "jāpārtrauc pašreizējais darbs citu steidzamu darbu dēḷ”. Pēc $M A{ }^{\circledR}$ apmācības uzlabojās reakcija uz dažiem stresu izraisošiem faktoriem. 